\title{
Regional Disparity Model Before and After OTSUS in Aceh Province
}

\author{
Devi Andriyani ${ }^{1}$, Hijri Juliansyah ${ }^{2}$, Hafizh Maulana ${ }^{3}$, Cut Putri Mellita sari ${ }^{4}$ and Umaruddin \\ Usman $^{5}$ \\ \{ deviandriyani@unimal.ac.id ${ }^{1}$, hijrijuliansyah@unimal.ac.id², hafiizhmaulana2@gmail.com³ \\ Cmellita0674@gmail.com4,Umaruddin@unimal.ac.id $\left.{ }^{5}\right\}$ \\ 1,2,4,5 Faculty of Economic and Business, Universitas Malikussaleh Lhokseumawe, Indonesia \\ ${ }^{3}$ FakultasEkonomi dan Bisnis Islam UIN Ar-Raniry Banda Aceh, Indonesi
}

\begin{abstract}
The allocation of OtonomiKhusus (OTSUS) funds for the Province of Aceh becomes a source of revenue that is able to increase the regional fiscal level. This study aims to identify regional disparities in Aceh and the implication of OTSUS fund allocation against inequality. The analysis model uses the Williamson index and Theil Index, which is then performed multiple linear regression analysis of time series analysis. The results show that the regional disparities in Aceh Province during the OTSUS period have decreased. The allocation of Otsus funds has a significant impact on regional disparities. The gap in the OTSUS period has tended to decline, with a decrease of 65 percent. Human Development Index and economic growth are determinants that can reduce regional disparities in Aceh.
\end{abstract}

Keywords: Regional, Disparity, OTSUS

\section{Introduction}

A new era in Indonesia's economic development is marked by the birth of the regional autonomy law through Law Number 22 of 1999 concerning Regional Government and Law Number 25 of 1999 concerning financial balance which was subsequently revised into Law Number 23 and Law 32 In 2004. The legislation provided space for each region to regulate economic activities and develop region independently. One important point in the regional autonomy policy regulates the financial relations between the Central and Regional in order to support the implementation of development, which is referred to as the balancing fund. In accordance with Law No. 32 of 2004 concerning Regional Government, the Balancing Fund is divided into three groups, namely the General Allocation Fund (DAU), Special Allocation Fund (DAK) and Revenue Sharing Fund (DBH). In its development, the balancing funds of the Regional Centers also stipulated the Special Autonomy (Otsus) areas that received additional Otsus funding allocations. The Province of Aceh is constructed as one of the recipient provinces of the Special Autonomy Fund allocation. The management of the Special Autonomy Fund for Aceh is based on government regulations (in Aceh called Qanun) in Qanun No. 11 of 2006, Qanun No. 2 of 2008 and Governor's Decree No. 48 of 2009.

Historically, the determination of Aceh as the recipient of the Special Autonomy Fund was inseparable from the conflict between Aceh and the Central Government. The Aceh conflict and the Government of the Republic of Indonesia (RI) took place from 1953-1961 led by TeukuDaudBeureueh and continued from 1976-2005 through the Free Aceh Movement (GAM). After the peace agreement of the Helsinki MOU, Law No. 11 of 2006 concerning the Government of Aceh was born. One of the consequences of the law is the establishment of Aceh as an area that receives Special Autonomy funds which amounts 2 percent of the 
national DAU allocation for 15 years starting from 2008. The obtaining Special Autonomy Funds has increased fiscal financial resources for Aceh, where since 2008 the Special Autonomy Fund has become the largest fiscal source for Aceh Government revenues in proportion to 62 percent of the provincial budget in 2010, or around 25 percent of the total budget of all District / City regions in Aceh (Special Autonomy Study, 2011). Although Aceh has a budget that is abundant, the performance of Aceh's economic growth is slow, following the performance of Aceh's economic growth during 2000-2015.

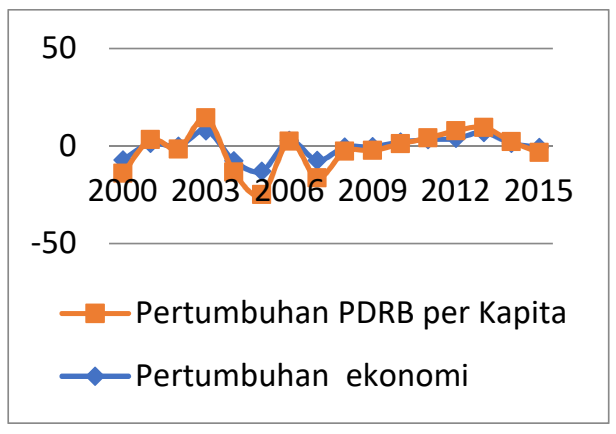

Fig. 1. Performance of Economic Growth and GRDP per Capita in Aceh Year2000-2015 Source: BPS Aceh Province (processed)

Aceh's economic performance in the long-term period shows a fluctuating situation, with a cycle of decreasing economic rates that often occur, especially in the period before 2008 . This was due to the deteriorating economic situation during the conflict and the 2004 Tsunami disaster. The average economic rate in 2000-2008 shows a negative trend of $-2.63 \%$ (economic growth) and $-3.23 \%$ (GRDP per capita growth). The stability of the economic rate occurred in the era of rehabilitation and reconstruction of post-tsunami in Aceh (2005-2009), although it still experienced a slowdown. The allocation of special autonomy funds that began in 2008 has not driven the economy to a positive trend, recorded in 2015 the rate of economy and per capita GRDP decreased by $-0.75 \%$ and $-2.66 \%$.

One of the main reasons why the role of transfer funds from the center is so important is to ensure the archievement of minimum standards of public Service throughout the country and reduce disparities between regions (Simanjuntak, 2002).

The implementation of development programs as outlined in the provincial and district / city development programs in Aceh must pay attention to the balance of development progress between regencies / cities which to be used as the basis for the use of special autonomy funds whose managing the Aceh Provincial Government (Yani, 2009). Given the strategic role of the Special Autonomy Fund, the management and utilization of the special autonomy fund arenot only to increase the rate of economic growth, but also to be able to achieve the target of regional development equality. Ideally, the special autonomy fund provided by the central government can overcome development gaps between regions and reduce disparity space.

Based on the background and problems that arise, then the formulates two problems i.e.(1)Is the income disparity occur in the District / City of Aceh Province before and after the implementation of theOtsus? (2) Does the allocation of the OTSUS funds have an impact on reducing regional disparity in Aceh Province? 


\section{Literature Review}

The phenomenon of the relationship between economic growth and income disparity was introduced by Simon (Kuznets, 1955) which illustrates the relationship between per capita income and evenness of income distribution in reverse U-shaped letters (Todaro and Smith, 2015). The relationship between per capita income and of income distribution illustrates at the beginning of the development phase, the distribution of income between households will tend to be uneven, but after reaching a certain level of development, distribution of income will be more evenly distributed (Nemati and Raisi, 2015).

(Dartanto and Brojonegoro, 2013) in their research on "The Impact of the Fiscal Decentralization on Economic Growth and Disparity between Regions" construcs a simultaneous econometric macro model dividing into macroeconomic blocks and regional financial blocks. Balancing fund policies whics is diriving from profit sharing funds (Land and Building Taxes, Land and Building Rights Acquisition Fees (BPHTB), Profit Sharing Taxes (PPH), and General Allocation Funds (DAU) exacerbate disparities between regions. The research concludes that the impact of fiscal decentralization policy has not been able to reduce disparities between regions.

(Liang, 2008) describesthat the pattern of relations in the development of the financial sector and economic growth which have implications for disparities between regions in China, especially the gap between coastal and land areas. This study seeks to explore that how the state of the macro economy in China after the enactment of China's economic system dualism (capitalist nature for the coastal and socialist regions for the mainland). The conclusion of this study shows that the development of the financial sector significantly increases the economic growth of coastal areas, but does not affect the land area.

Studies related to fiscal decentralization in overcoming development inequality were carried out by (Bonet, 2005) who looked at the link between decentralization and the shift in regional structure and inequality in Colombia. The results show that fiscal decentralization has an impact on increasing income inequality between regions. but economic openness and economic agglomeration have a negative impact on inequality. therefore, changes in economic structure are needed.

\section{Methodology}

The research usesdisparity analysis and multiple linear regression data models. The analysis period is used in the span of the period before Otsus (2000-2007) and after Otsus (2008-2016).

\subsection{Inter-regional Income Disparity Formulation WilliamsonIndex}

$I_{\mathrm{w}}=\frac{\sqrt{\sum_{\mathrm{i}=1}^{\mathrm{n}}\left(y_{i-\overline{\mathrm{y}}}\right)^{2} \cdot{ }^{A_{i}} / A_{t o t}}}{\overline{\mathrm{y}}}$

(Kuncoro, 2013)

IW: Williamson Index (income disparity between districts / cities inAceh province), where $0<\mathrm{Vw}_{\mathrm{W}}<1$

$Y_{i}$ : GRDP per capita from the District / City of Aceh Province

$\overline{\mathrm{y}}$ : $\quad$ Aceh Province per capita GRDP

$A_{i}$ : Population of Aceh Province

$A_{\text {tot }}$ : Total population of the entire province of Aceh 


\subsection{IndeksEntrophyTheil}

$\mathrm{I}(\mathrm{y})=\sum_{\mathrm{r}=1}^{\mathrm{R}} \log \frac{\mathrm{Y}_{\mathrm{r}}}{\mathrm{N}_{\mathrm{r}} / \mathrm{N}}+\sum_{\mathrm{r}=1}^{\mathrm{R}} \mathrm{Y}_{\mathrm{r}}\left[\sum_{\mathrm{i} \in \mathrm{r}} \frac{\mathrm{y}_{\mathrm{i}}}{\mathrm{y}_{\mathrm{r}}} \log \frac{\mathrm{y}_{\mathrm{i}} / \mathrm{Y}_{\mathrm{r}}}{\mathrm{N}_{\mathrm{r}}}\right]$

(Kuncoro, 2013)

Yr: Share of GDP in all districts / cities in the region $r$

yi: Share of GRDP in the regency / city to the total GRDP of Aceh Province

NR: Number of districts / cities in the region $\mathrm{r}$

N: The total number of districts / cities in Aceh Province

R: $\quad$ Total area of Aceh Province

r: $\quad$ consists of the south west, southeast, and north east regions

\subsection{Multiple Linear Regression Model}

Multiple linear regression model uses time series data to see the effect of economic growth, HDI, inflation, unemployment, and the Special Autonomy period on the gap index.

$V W_{t}=a_{t}+L n b_{1} P E_{t}+L n b_{2} I P M_{t}+$

$\mathrm{Lnb}_{3} I N F_{t}+\mathrm{Lnb}_{4} U N_{t}+b_{5}$ DUMMYOTSUS $+e_{t}$

Keterangan

$\mathrm{VW}_{\mathrm{t}}$ : Williamson index in year $\mathrm{t}$

$\mathrm{A}_{\mathrm{t}}$ : $\quad$ Intercept coefficient (constant)

$\mathrm{b}_{1}, \mathrm{~b}_{2}, \mathrm{~b}_{3}, \mathrm{~b}_{4}, \mathrm{~b}_{5}$ : Regression coefficient

$\mathrm{PE}_{t}$ : $\quad$ The rate of economic growth in the year $\mathrm{t}$

$\operatorname{IPM}_{\mathrm{t}}$ : $\quad$ Human Development Index in the year $\mathrm{t}$

$\mathrm{INF}_{\mathrm{t}}$ : $\quad$ Inflation in the year $\mathrm{t}$

$\mathrm{UN}_{\mathrm{t}}$ : $\quad$ Unemployment in the $\mathrm{Y}$ year

Dummy OTSUS $_{t}$ : Dummy varible to see Otsus,(2000-2007) and a value of 1 for the after Otsus (2008-2016)

$e_{i}: \quad$ Error term

\section{Result And Discussions}

\subsection{Disability Conditions of Aceh Province}

To see the disparity the study uses 2 measurement indexes; namely the Williamson index and TheilEntrophy Index. These two submissions were carried out with the aim of strengthening regional gap analysis in the province of Aceh. based on the measurements made, the gap index tends to decline in the period 2000-2016. But this decline still puts Aceh in a position with a moderate gap index. The following is a graph of measurements from the Gap Index with Williamson and theil measurement methods. 


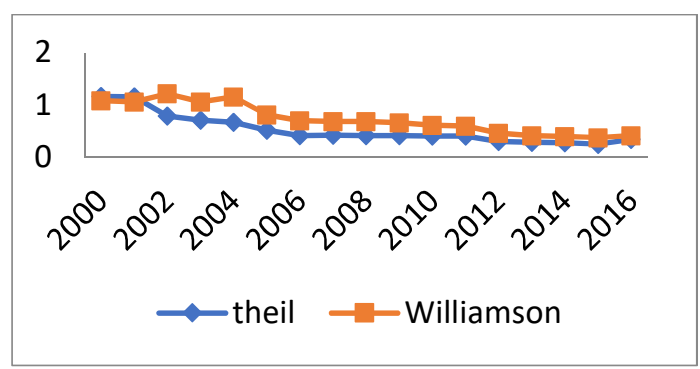

Fig. 2. Aceh Province Disaprity Trend Based on Entrophy Theil and Williamson IndexYear 2000-2016

The gap in the Province of Aceh shows that there is a trend of decreasing the disparity index from the period before OTSUS and after OTSUS. High disparities occurred in the 20022004 period, which was indicated by the effects of the Tsunami disaster and the Aceh conflict period. The gap has decreased as a result of the development of Aceh Rehabilitation and Reconstruction after the Earthquake and Tsunami. It is possible, the decline in the gap occurs because of economic growth in the majority of regions experiencing slowdown.

As for the concerns that arise from the results of the description of the Aceh gap, it appears to have increased in the 2014-2016 period. Although OTSUS funds have been allocated since 2008, the level of inequality is still high with a value of 0.36 (theil index) and 0.41 (Williamson index). It is probable that the gap index will be absorbed by properly regions that have not been able to manage the budget prudently and the high level of routine spending. Another justification of the gap due to the large number of oil and gas industries that was experiencing a decline and continued to be smaller.

\subsection{Analysis of the Williamson index regression model}

The Willamson index actually explains the gap with the district / city GRDP per capita database on the province's GDP per capita. Then the value or index of the gap is aggregated in the entire province of Aceh without dividing and grouping into specific regions

In the Williamson index gap model, a series of elaborations were carried out by adding independent variables in the form of Human Development Index (HDI), Economic Growth, Inflation, Unemployment, and Dummy OTSUS period. The results of the estimation of the equation model obtained the following results.

Tabel 1. Estimation Results of the Williamson Index Regional Gap Model

\begin{tabular}{llll}
\hline Variabel & \multicolumn{3}{l}{$\begin{array}{l}\text { Dependet VariabelIndeksWilliam } \\
\text { pson }\end{array}$} \\
\cline { 2 - 4 } & $\begin{array}{l}\text { Koefesie } \\
\mathbf{n}\end{array}$ & $\begin{array}{l}\text { Std.Erro } \\
\mathbf{r}\end{array}$ & T-Stat \\
\hline C & 7.05 & 1.78 & $\begin{array}{l}3.96\left(^{* * *}\right. \\
)\end{array}$ \\
\hline IPM & -0.09 & 0.03 & $\begin{array}{l}3.25(* * * \\
)\end{array}$ \\
\hline Growth & -0.03 & 0.01 & - \\
& & & $3.23(* * *$ \\
\hline
\end{tabular}




\begin{tabular}{llll}
\hline & & & ) \\
\hline Inflation & -0.01 & 0.01 & -1.39 \\
\hline $\begin{array}{l}\text { Unemplo } \\
\text { yment }\end{array}$ & -0.02 & 0.02 & -0.79 \\
\hline $\begin{array}{l}\text { Dummy } \\
\text { OTSUS }\end{array}$ & -0.35 & 0.08 & $\begin{array}{l}4.19(* * * \\
\text { ) }\end{array}$ \\
\hline $\mathrm{R}^{2}$ & 0,87 & & \\
\hline F-Stat & $14,72(* * *)$ & \\
\hline Dw-Stat & 1,7 & & \\
\hline
\end{tabular}

Source: Processed by the author with e-views ver 8.0

Information: $* * *$ significantat $\alpha 1 \%(\mathrm{p}<0.01)$; **significantat, $\alpha 5 \%(\mathrm{p}<0.05)$; *significantat $\alpha 10 \%(\mathrm{p}<0.1)$

The results show a high R-Squared value which is 86 percent. it means that the estimated model has a close relationship between independent and dependent variables. The determinant of the influence of HDI, economic growth, inflation, unemployment, and the OTSUS dummy on the regional gap can be explained by 87 percent, while the remaining 13 percent is explained by the other variables outside the equation model.

All ofthe independent variables simultaneously at 99 percent confidence level. Partially, the estimation results prove that there is a HDI variable, economic growth and dummy autonomy have a significant effect on regional disparity at 99 percent confidence level. The variables that have no partial effect are inflation and unemployment. Specifically, this equation model defines several things, including:

- The HDI has a significant and negative influence on the regional gap with a coefficient of -0.09 . This means that if the Aceh Province HDI increases 1 percent, the regional gap will decrease by 9 percent assuming other variables.

- Economic growth has a significant and negative influence on the regional gap of -0.03 . The interpretation is, an increase in economic growth of 1 percent will have an impact on a regional gap of 3 percent assuming other.

- Inflation does not have a significant effect on regional disparities, although the result of the coefficient is negative. This is indicated that theelasticity of price increasing occurs within a short period of time, so that price is fluctuates.It is do not directly affect the disparity between regions. Another argument is that the source of disparity in Aceh Province is not derived from the symptoms of inflation due to regional differences in the high level of inequality but occured from due to the price of goods is more stable because it is supported by the smooth distribution of goods and government intervention.

- Even though the coefficient value is negative, Unemployment does not have a significant effect on regional disparities. The level of regional disparity is not affected by the high open unemployment rate. It shown that the Aceh Province workforce is mostly working in the informal sector. The source of unemployment does not become a determinant to reduce regional disparities. This means that the workforce of the Aceh Province is faced with a low absorption of labor in the formal sector, and the majority of the workforce is in the agricultural sector.

- The impact of the Aceh OTSUS period significantly affected the regional gap with a coefficient of -0.35 . The interpretation of this Otsus shows dummy that the gap that occurred after Aceh's OTSUS was smaller than before OTSUS with a difference of 35 
percent. Policy in other words, the gap in the OTSUS period decreased by 65 percent smaller than before OTSUS

\subsection{Discussion}

Based on the results of the estimates above, the discussion will focus more on an indepth study of OTSUS Aceh and its relation to the development gap in Aceh Province. The scope of the first discussion, is that the OTSUS Aceh regulation and the changes that has been occurred. Secondly the impact of the development gap in the Province of Aceh before and after the allocation of Otsus funds. Third, the impact of the allocation of Aceh's OTSUS funds on inequality in Aceh Province, where there were changing ups and downs in the allocation of qanun regulations.

\subsubsection{Regulation of OTSUS Aceh Fund Management}

In accordance with Law No. 32 in 2004 concerning Regional Government, the Balancing Fund is divided into three groups, namely the General Allocation Fund (DAU), Special Allocation Fund (DAK) and Revenue Sharing Fund (DBH). In its development, the balancing funds of the RegionCenters also stipulated the Special Autonomy (Otsus) areas that received additional Otsus funding allocations.

Aceh Province is designated as one of the provinces (together with Papua) which is receivingthe Special Autonomy Fund allocation. Aceh has two attributes of special autonomy. First, is through on Law Number 18 in 2001 concerning Special Autonomy for the Province of NAD, and the second is through Law No. 11 in 2006 concerning the Government of Aceh. In its development the Aceh OTSUS Qanun continued to experience changes and improved governance before the issuance of the Aceh Qanun No. 1 which is the Special Autonomy Fund in 2008 and Governor's Decree No. 48 in 2009.

In the period of 2013 there was a change in the governance of OTSUS Aceh with the issuance of Qanun No. 2 in 2013 concerning Procedures for Allocating Additional Funds for Oil and Gas Products and the Use of Special Autonomy Funds. The last change occurred in 2016 marked by the ratification of Qanun No. 10 in 2016 concerning the Second Amendment to the Aceh Qanun Number 2 in 2008 concerning Procedures for Allocating Additional Funds for Oil and Gas Products and the Use of Special Autonomy Funds.

\subsubsection{Dummy period gap before Otsus and After Otsus}

The OTSUS Aceh period began in 2008, which providing district / city authorities with the authority to manage OTSUS budgets. The changes that occur in the management of Aceh's OTSUS funds are considered to affect the level of development gap. Based on the estimation results, the gap in the OTSUS period decreased, with a difference of 35 percent. Inother words, during OTSUS since 2008 the gap in Aceh decreased by 65 percent.

When looking at the data on the graph of the regional gap index with the Willamson Index and Theil Index, the gap has increased in 2015-2016. During this period there was a fundamental change in the policy of allocating funds for OTSUS Aceh with the existence of Qanun No. 2 in 2013 and the Qanun N0. 10 in 2016, by cutting the authority of the district / city in managing OTSUS funds which amount of 40 percent. There is a strong assumption that the development program proposed by the district / city has been hampered by a proposal mechanism that is centered on the Aceh Provincial Government.

The results of a study conducted by the Aceh Province Bappeda and PPKD found that the absorption of OTSUS budgets by the province was slightly better than that of the city 
districts. In 2014 the absorption rate in districts / cities accounted for 89 percent, slightly higher than the province which accounted for 93 percent. One of the obstacles to the relatively low absorption of districts / cities is the absence of clear criteria during planning in the early stages, so that there are several programs / activities which have not been approved by the province, while the time for changes to program proposals is also relatively limited. The development gap caused by OTSUS Aceh has been relatively declining, despite changes in the governance of fund allocation between the Province and District / City.

The HDI variable in the gap analysis shows a significant influence in reducing the regional gap rate. The HDI is one of the indicators for measuring the allocation of OTSUS funds. Districts / cities with a low HDI receive larger OTSUS funds. An increase in the HDI of 1 percent will be able to reduce the regional gap by 9 percent. The HDI refers to 3 main indicators, namely education, health, and purchasing power.

Variable Economic Growth also becomes a significant variable in reducing regional disparity in Aceh Province. If Economic Growth increases 1 percent, the gap can be reduced by 3 percent. Qiaou, et All (2002) explained that fiscal decentralization has a significant effect on economic growth, where there are increasing fiscal budgets, economic growth is increasing even though the relationship is not linear.

\section{Conclusion}

Based on the research that has been done, it can be concluded that the regional disparity that occurred in Aceh Province has decreased during the allocation of OTSUS funds since 2008. However, in some conditions such as 2014-2016 has increased.

The estimation results in the regional gap model with inter-time data through the Williamson index prove that the gap has decreased along with the allocation of OTSUS funds in Aceh Province since 2008, with a difference of 35 percent. IPM variables and economic growth are determinants that can significantly reduce Williamson's gap index.

\section{References}

[1] Bonet, J. . (2005) Decentralization, Structural Change and Regional Disparities in Colombia. United States: University of Illinois at Urbana-Champaign.

[2] Dartanto, T. and Brojonegoro, B. P. S. (2013) 'Dampak Desentralisai Fiskal di Indonesia Terhadap Pertumbuhan Ekonomi dan Disparitas Antar Daerah: Analisa Model Makro Ekonometrik Simultam', Indonesian Journal of Economic and Development, 4(1), pp. 17-38.

[3] Kuznets, S. (1955) 'The American Economic Review', American Economic Review, 45(1), pp. 1-28. doi: 10.1257/aer.99.1.i.

[4] Liang, Z. (2008) 'Financial Development, Growth, and Regional Disparity in PostReform China', Inequality and Growth in Modern China, 3, pp. 3-20. doi: 10.1093/acprof:oso/9780199535194.003.0006.

[5] Nemati, M. and Raisi, G. (2015) 'Economic Growth and Income Inequality in Developing Countries', International Journal of Life Sciences, 9(6), pp. 79-82. doi: 10.3126/ijls.v10i1.14509.

[6] Simanjuntak, R. (2002) Dana AlokasiUmum: Konsep, Hambatan, danProspek di Era Otonomi Daerah. Jakarta: Penerbit Buku Kompa.

[7] Todaro, M. P. and Smith, S. C. (2015) Economic Development. 12 th Edit. New York: The George Washington University.

[8] Yani, A. (2009) Hubungan Keuangan antara Pemerintah Pusat dan Daerah di 
Indonesia. Jakarta: Rajawali Persamaan. 